\title{
Compulsory Motherhood, Paternalistic State?
}

"Oleksandra Tarkhanova makes a significant contribution to the growing body of research on the intersection of neoliberal reforms, conservative anti-gender ideology and women's status in the countries of Eastern Europe. Her pioneering feminist analysis of the Ukrainian welfare state is based on a thorough investigation of social policy debates and legislation in the country from independence to the postMaidan era. The current culture war on 'gender ideology' makes her findings relevant beyond the Ukrainian case."

-Tatiana Zhurzhenko, Lecturer at the University of Vienna, Austria

"Essential reading for scholars of gender and social policy studies in Eastern Europe, this book is an exciting intervention in feminist critiques of the effects of neoliberalism on the gender dimensions of social policy debates in post-socialist states. Tarkhanova's diachronic perspective, tracking gender policy in Ukraine from 1985 to 2017, provides crucial insights for understanding 'anti-gender,' anti-feminist movements in contemporary Ukraine and neighbouring countries. Key policy areas under focus are family law and state welfare, the Labor Code, and women's rights and gender equality. Crucially, Tarkhanova draws on her extended Ukrainian case study to engage with broad feminist critiques of neoliberalism, extending the case's relevance far beyond discussions of gender policy in Central and East Europe."

- Sarah D. Phillips, Professor of Anthropology, Director of the Robert F. Byrnes Russian and East European Institute, Indiana University, USA 


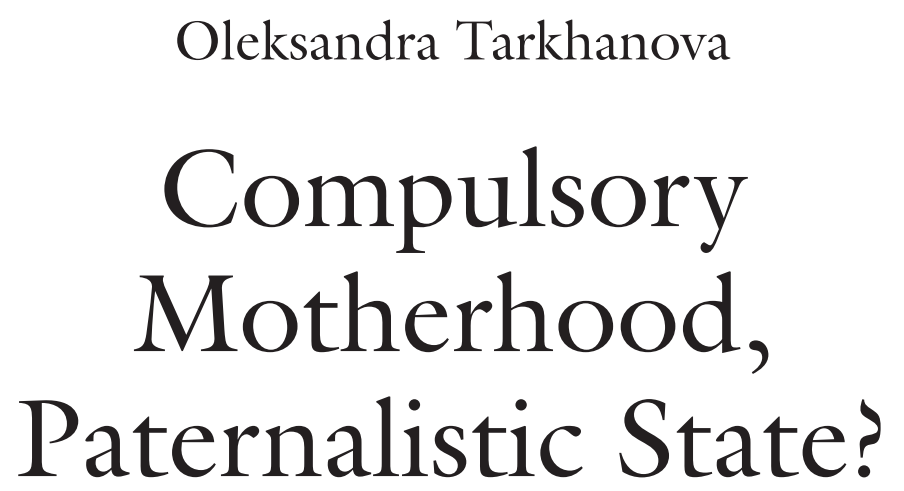

Ukrainian Gender Politics and the Subject of Woman

palgrave macmillan 
Oleksandra Tarkhanova

Centre for Governance and Culture in Europe

University of St. Gallen

St. Gallen, Switzerland

ISBN 978-3-030-73354-4

ISBN 978-3-030-73355-1 (eBook)

https://doi.org/10.1007/978-3-030-73355-1

(C) The Editor(s) (if applicable) and The Author(s), under exclusive licence to Springer Nature Switzerland AG 2021

This work is subject to copyright. All rights are solely and exclusively licensed by the Publisher, whether the whole or part of the material is concerned, specifically the rights of translation, reprinting, reuse of illustrations, recitation, broadcasting, reproduction on microfilms or in any other physical way, and transmission or information storage and retrieval, electronic adaptation, computer software, or by similar or dissimilar methodology now known or hereafter developed.

The use of general descriptive names, registered names, trademarks, service marks, etc. in this publication does not imply, even in the absence of a specific statement, that such names are exempt from the relevant protective laws and regulations and therefore free for general use. The publisher, the authors and the editors are safe to assume that the advice and information in this book are believed to be true and accurate at the date of publication. Neither the publisher nor the authors or the editors give a warranty, expressed or implied, with respect to the material contained herein or for any errors or omissions that may have been made. The publisher remains neutral with regard to jurisdictional claims in published maps and institutional affiliations.

Cover pattern (C) Alex Linch shutterstock.com

This Palgrave Macmillan imprint is published by the registered company Springer Nature Switzerland AG.

The registered company address is: Gewerbestrasse 11, 6330 Cham, Switzerland 
To my mother 


\section{ACKNOWLEDGMENTS}

I am deeply indebted to many people and institutions for their support during the research for this book. This work would not be possible without the financial and institutional support of the Bielefeld Graduate School in History and Sociology (BGHS). My deepest gratitude goes to Tomke König and Andreas Vasilache, who supported, guided, and encouraged me. Their insightful, considerate, and patient advice and support have been crucial for this research. Many people at the BGHS deserve special credit for always being there to assist with bureaucratic, technical, and personal matters: Sabine Schäfer, Frank Leitenberger, Miriam Kanne, Rita Gaye, and Eleonora Wagner. I am also grateful to the Bielefeld Young Researchers' Fund and the German Academic Exchange Service for additional research funding for this project.

The (BGHS) was more than a place of institutional support. It was first and foremost people who made this time one of the best times of my life, despite, or maybe due to, it also being a time of our collective misery. I am very grateful to all of you, and I cherish the time of open doors, long tea breaks, and a wealth of support you all gave me: Lili Zhu, Rümeysa Gündüz Can, Çağdaş Can, Jana Hoffmann, Dorothee Wilm, Frank Leitenberger, Katharina Hoß, Cleovi Mosuela, Susanne Schultz, Kathrin Mittelstaet, Daniele Toro, and many others. I am grateful to Zoltán Simon, the intellectual sparring partner in frequent disputes on questions ranging from decoloniality to food preferences, who read and commented 
on numerous early drafts and final versions of chapters in this book, shaping my thinking more than he knows. Christopher Dorn deserves a special mention as the best office mate one could ask for. Thank you for saving my sanity in more ways than I could describe and for being so generous with your time every time I needed help. Our theoretical discussions about our respective works, but also life in general, got me through some of the most challenging times.

Much of the work done for this book was presented at workshops, colloquia, and conferences over the years. I would especially like to acknowledge the research colloquium of Tomke König and its participants, whose continuous feedback for all these years helped me in the most profound way to make this research what it is. Especially, I would like to thank Holly Patch and Susanne Richter for their consistent intellectual contribution and unwavering personal support. Writing this book was an individual and, at times, lonely struggle, but I never felt alone with the two of you. Our chat history is one for the books. Thank you, Holly, for being incredibly generous and reading the draft of this book before anyone else, and working so hard on making it better. I would also like to thank Thomas Faist and participants of the research colloquium 'Transnational Studies' for generous contributions and support exactly at the right time. Additionally, I would like to thank Ursula Mense-Petermann and the participants of her research colloquium for valuable and useful feedback. It is impossible to name everyone I met at numerous conferences and meetings and to account for the profound way your comments, questions, and curiosity shaped my work.

A part of this research was conducted during a stay at the Russian and East European Institute at Indiana University, Bloomington. Sarah Phillips welcomed me into her team and her home, and I am forever grateful for her encouragement, ongoing intellectual conversation, and personal support. The time in Bloomington would not be what it was for me personally and for my work if not for Karissa Jackson. Thank you for becoming a true friend and for encouraging me when I needed it most.

A lot of the work on the final manuscript was accomplished while I was a postdoctoral fellow at the Center for Governance and Culture in Europe at the University of St. Gallen with the generous support of the State Secretariat for Education, Research, and Innovation in Switzerland. I am grateful to Ulrich Schmid for giving me very timely, thoughtful, and incredibly helpful advice on the process of publication. 
I would like to thank Tom for motivating and supporting me for all these years, but also for consistently reminding me that there is more to life than just work. I relied on you in more ways than you know while making big research decisions and small everyday efforts of editing. Thank you for joining me on much-needed escapes and adventures. Finally, I am grateful to my family for always showing unconditional love and acceptance. Without my mother, her understanding, love, support, and humor, neither this work nor anything else would be possible. 


\section{Contents}

1 Studying Ukrainian State: Gender Policy and Politics Under Changing Conditions

Gender Policy and Gender Politics: Setting the Research

Framework

Traditionalization, Liberalization, or More? Soviet, Post-Soviet, and Post-Maidan Gender Transformations

State: A Feminist Take

Rethinking Policy Discourse Analysis

Analyzing Change

A Note on Policymaking in Ukraine

34

Structure of the Book

Bibliography

2 Compulsory Motherhood

New Welfare System: Preserving Foundations, Changing Tools

Ukrainian Pronatalism and Familialism: 'Upbringing' in the Name of the Nation

The 'Traditional Ukrainian Family': From Ideal to Average Bibliography

3 Working and Mothering

Is the Free Market 'Bad' for Women, and Are Women 'Bad' for the Free Market? 
xii CONTENTS

The Working Mother: Reconciling Working and Caring

Protecting Female Workers and Rewarding Reproduction in

Pension Law

164

Bibliography

186

4 Ukrainian Woman and Equality 189

The Debt That Cannot Be Paid 190

Equality in Difference $\quad 208$

Anti-genderism 233

Bibliography $\quad 252$

5 Conclusion: Gender Politics and Conservative Neoliberal Transformations in Ukraine $\quad 257$

The Regime of 'Compulsory' Motherhood 257

Conservative Neoliberalism and Gender 264

Ukrainian Gender and Anti-gender Discourses in the

European Context 271

Theoretical Prospects 276

Bibliography $\quad 279$

$\begin{array}{ll}\text { Index } & 285\end{array}$ 